\title{
Ethnobotany and Pharmacognosic Characterization of Acanthospermum hispidum (Asteraceae), A Medicinal Plant widely used in Traditional Medicine in the Central West Region (Burkina Faso)
}

\author{
Jotham Yhi-pênê N'do ${ }^{1}$ *, Adama Hilou ${ }^{1}$, Dramane Pare ${ }^{1}$, \\ Samson Guenne ${ }^{1}$ and André Tibiri ${ }^{2}$
}

${ }^{1}$ Laboratory of Biochemistry and Applied Chemistry (LABIOCA) / University of Ouaga I Pr Joseph KI-ZERBO, 03 BP 848 Ouagadougou 03, Burkina Faso

${ }^{2}$ Institute for Research in Health Sciences (IRSS / CNRST), Department of Medicine and

Traditional Pharmacopoeia (MEPHATRA-PH), 03 BP 7192 Ouagadougou 03, Burkina Faso

\author{
*Corresponding author
}

\section{A B S T R A C T}

\section{Keywords}

Acanthospermum

hispidum,

Ethnomedicine,

Histochemistry,

Burkina Faso

Article Info

Accepted:

04 August 2019

Available Online:

10 September 2019
Medicinal plants are an important source for the research of active molecules against diseases. The plants used in this setting are rich in therapeutic substances. This study aimed to collect the ethno-medical use of Acanthospermum hispidum in the Central West region from resource persons and to determine these pharmacognosic characteristics. A survey collected information on Acanthospermum hispidum using a sheet. The whole plant has been used for pharmacognosic characterization through histochemistry and biological activities. There was strong use of the plant in the Central West region. The majority of the people surveyed were men (76.40\%). The histochemistry of Acanthospermum hispidum allowed the detection of phytochemical groups. Biological activities showed that the ethanolic extract had a good ability to trap free radicals, with a 50\% IC of $21.46 \pm 1.85$ $\mu \mathrm{g} / \mathrm{mL}$ for rat liver lipids. These results are probably a scientific source for the use of Acanthospermum hispidum as a medicinal plant in the Central West region. The high use of this plant could be explained for its wealth of secondary metabolites.

\section{Introduction}

Asteraceae or Compositae constitute one of the largest families of Angiosperms (Cronquist 1981), containing more than 1500 genera (25000 known species) or nearly $10 \%$ of the total flora of the world (Verdi et al., 2005). Although 98\% of Asteraceae are herbaceous, shrubs, lianas, trees, there are also some aquatic species. The main characteristic of this family is the presence of many flowers united in a capsule. The genus Acanthospermum includes annual herbaceous plants that are erect or prostrate. The leaves are simple, opposite, with dentate or entire margins, and the inflorescence is axial or terminal, with yellow flowers (Mallmann et al., 2018). 
Acanthospermum hispidum is a branched plant that can reach $0.6 \mathrm{~m}$ in height. The stems of this plant are covered with tufted hairs and small glandular hairs.

The leaves are elliptical, oval $1.5 \mathrm{~cm}$ to $7 \mathrm{~cm}$ long. When mature, Acanthospermum hispidum bears yellow flowers. Each head has 5-9 flowers; the petals of rays of about $1.5 \mathrm{~mm}$ are pale yellow. The flowers of the disc in the center of the head are sterile. Spiny fruits $5 \mathrm{~cm}$ to $10 \mathrm{~cm}$ long are flattened and triangular in shape. These fruits are covered with stiff hooked hairs and have either a pair of straight or curved spines at the top.

The ruffled and grouped appearance of the fruits on each head is an essential criterion for the identification of this species of plant (Gomathi et al., 2013). These spines, arranged in the form of stars, constitute distinctive points of this species (Goodridge, 2007). Acanthospermum hispidum (DC), is a medicinal plant (El-Ghani 2016). It is used in traditional medicine in the Central West region for the treatment of several diseases.

The objective of this study was to determine the ethnomedicine of Acanthospermum hispidum in the Central West region and to elucidate these pharmacognosic features. Thus pharmacognosic tests and biology activities have justified this important use of Acanthospermum hispidum by the population of the Central West region for their health problems.

\section{Materials and Methods}

\section{Laboratory equipment}

\section{Appliances}

Scale (Radwag Poland), UV-Visible Spectrophotometer (epoch 251465, Biotek Instruments, USA), Steamer (Momment,
Beschickung, Loadig, Model 100-800), Rotary Evaporator (Büchi 461) with Vacuum Pump, Bain Marie (Büchi B-480, Switzerland), magnetic stirrer (Fisher Scientific, Topmix), sonicator (Elma Gemany), refrigerated centrifuge (Eppendorf, 5702 RH).

\section{Glass}

Column, Flask, Graduated cylinder, Erlenmeyer flask, Volumetric flask, Test tubes, Separating funnel.

\section{Reagents}

Sigma reagents (Steinheim, Germany): methanol, hydrochloric acid, chloroform, ether, lugo, mayer reagent, Physiological Solutions: Phosphate Buffer, Tris Buffer, Dimethylsulfoxide (DMSO), Sodium Hydroxide, Sodium Chloride, Potassium Chloride.

Consumables: Aluminum Foil, Surgery Kit, Porcelain Mortar, Microscope Gloves, Slides and Slides, Bleach, Blotting Paper, 96-Well Microplate, Micropipettes, Eppendorff Tubes, $90^{\circ}$ Alcohol. They are all analytical grade.

\section{Plant material}

The entire plant of Acanthospermum hispidum was harvested in Reo (province of the sanguie). The plant has been identified at the Laboratory of Plant Ecology and Botany of University Ouaga I Pr Joseph KI-ZERBO. Specimens were deposited in the herbarium of the biodiversity laboratory under the identification code ID 16875.

To obtain extracts, the harvested plants were dried at the Laboratory of Biochemistry and Applied Chemistry (LABIOCA) at room temperature, at room temperature. Shelter from the sun, then the dry plant material was sprayed. 


\section{Ethnobotanical survey}

\section{Land of inquiry}

The Central West region covers an area of $21,891 \mathrm{~km}^{2}$, or $8 \%$ of the national territory (Ministère et al., 2010). It is limited to the East by the Central Plateau, Central-South and Central regions, to the North by the Northern region, to the west by the Mouhoun region and South-West regions, and to South by the Republic of Ghana.

The Central West region is subdivided into 4 provinces, 4 urban communes, 38 departments, 34 rural communes and 563 villages. The provinces of the region and their capitals in brackets are the following: Boulkiemde (Koudougou), Sanguie (Reo), Sissili (Leo) and Ziro (Sapouy) (Ministère et al., 2011). The chief town of the region is Koudougou and the chief towns of the provinces mentioned above constitute the urban communes (Ministère et al., 2010).

\section{Conduct of the investigation}

The investigation consisted of going to the field with a recommendation. The interview process was semi-structured (Yelemou et al., 2007) with traditional healers and herbalists. The interest of this survey was to record knowledge transmitted orally by persons holding knowledge inherited and/or revealed on the ethno-medicinal use of this plant.

The exchanges with the respondents were carried out in french and in local languages (lyele, moore, dioula). The conversations were around the questions contained in the survey card.

The questions asked allowed to have information on the use of Acanthospermum hispidum, the method of preparation, the mode of administration, the pathologies treated, the type and the duration of the treatment.

\section{Data processing}

The herbaria of Acanthospermum hispidum have been realized and authenticated. The completed survey forms were processed using Sphinx V5 software to obtain certain parameters on the plant.

The usual value (UV) of treated disease for each use category was evaluated to show the importance that individuals place on Acanthospermum hispidum in the locality to treat a given disease. It is obtained by calculating the following ratio: $\mathrm{UV}=\Sigma \mathrm{U} / \mathrm{N}$ Where $\mathrm{U}$ represents the number of times the species is cited for a use category (disease) and $\mathrm{N}$ the total number of informants (Sarr $e t$ al., 2013).

We used the Informal Consensus Factor (ICF) that we re-adapted to characterize the species in five (5) categories of use: abdominal pain, eruptive fever, hepatobiliary disorders, microbial infections and other diseases (epilepsy, mental disorders, gonorrhea, sexual impotence, hernia, joint pain, dental, fractures, pneumonia). It was used to estimate the variability of Acanthospermum hispidum uses. Its value varies between 0 and 1 . It is obtained by using the following formula (Canales et al., 2005).

$\mathrm{ICF}=\mathrm{Nur}-\mathrm{Nt} /(\mathrm{Nur}-1)$ With Nur is the number of times the species is cited for a particular category of use and Nt is the total number of times that the species is used by all informants for this same category (Cheikhyoussef et al., 2011). Loyalty Level (LL) (Cheikhyoussef et al., 2011) highlights the importance that populations place on Acanthospermum hispidum for its role. It is calculated by the following formula:

LL $(\%)=\mathrm{Np} / \mathrm{N} \times 100$ Where $\mathrm{Np}$ is the number of citations of the species for a use category and $\mathrm{N}$ is the total number of uses for all categories. 


\section{Pharmacognosic characterization}

\section{Structure of the drug}

The plant material (whole plant of Acanthospermum hispidum) after being dried under the required conditions, was sprayed. This powder has been the subject of macroscopic and microscopic observations.

\section{Histochemical characteristics}

Histological sections were performed on the stems and roots of Acanthospermum hispidum to identify secondary metabolites in plant tissues.

\section{Double carmino-green coloration}

Carmino-green double staining was performed on sections of Acanthospermum hispidum. For this purpose, the sections were soaked in a solution of sodium hypochlorite and then rinsed three times. They were then dipped in a coloring solution of carmino-green Mirande for 5 minutes. The stained sections were rinsed with distilled water and then mounted between slide and coverslip in a drop of glycerin for observation under a microscope (Nacoulma 1996).

\section{Detection of secondary metabolites}

\section{Detection of flavonoids}

Detection of flavonoids in plant tissues was achieved by mounting the sections in a 5\% $\mathrm{NaOH}$ solution. The presence of flavonoids (flavones) in the tissues is indicated by a yellow or orange-yellow coloring.

\section{Detection of tannins}

The detection of tannins in the tissues of Acanthospermum hispidum was performed by mounting the sections in a solution of $\mathrm{FeCl}_{3}$
(1\%). The appearance of blackish blue or blackish green in the tissues, indicates the presence of tannins.

\section{Detection of alkaloids}

A brown precipitate in the cell vacuoles using lugol as a reagent on the sections indicates the presence of alkaloids.

\section{Extraction}

\section{Extraction by ethanol maceration}

The whole plant powder of Acanthospermum hispidum was mixed with ethanol (in the proportions 5\%) and stirred for 24 hours. After filtration under reduced pressure, the filtrate obtained was frozen and then lyophilized.

\section{Extraction by aqueous decoction}

In a flat-bottomed flask was mixed Acanthospermum hispidum powder with distilled water in the proportions 1:5. The mixture was homogenized and boiled under reflux for 30 minutes. The contents of the flask, after being allowed to warm, were spilled in centrifuge tubes. The supernatant obtained was concentrated, frozen and freezedried.

\section{Inhibition of lipid peroxidation of rat tissue liposomes}

The potential of both forms of extracts to protect biomembranes from four rat organs (liver, kidney, pancreas and lungs) against ferrous $\mathrm{Fe}^{2+}$ ion and sodium nitroprusside was evaluated respectively according to the methods described by $\mathrm{Su}$ et al.,(Su et al., 2009) with some modifications. The percentages of inhibition were determined at different concentrations and then reported on a curve to derive the inhibitory concentration $50 \%$ (IC 50\%). These tests were performed in 
triplicate independently. The results were expressed as mean \pm standard deviation.

\section{Trapping hydrogen peroxide}

Hydrogen peroxide has a relatively long life and is capable of causing damage far from its place of production. It diffuses easily through the cell membrane. Under oxidative stress conditions, it can give rise to the hydroxyl radical in the presence of metal ions. The ability of ethanolic and aqueous extracts of Acanthospermum hispidum to trap hydrogen peroxide was evaluated according to the method described (Ogbunugafor et al., 2012). The reaction mixture consisting of $100 \mu \mathrm{L}$ of extract and $100 \mu \mathrm{L}$ of hydrogen peroxide (100 $\mathrm{mM}$ ) was incubated for 10 minutes at room temperature. Residual hydrogen peroxide was measured at $230 \mathrm{~nm}$ against a blank containing only the phosphate buffer. The activity of the hydrogen peroxide trapping extract was expressed as a percentage of trapping hydrogen peroxide relative to the control without extract. The experiment was carried out in triplicate (independent tests) and ascorbic acid was used as a reference substance.

\section{Statistical analysis tools}

The results were expressed as the mean value of several independent experiments \pm standard deviation. The MS Excel software was used to obtain the graphs of the survey results. For statistical analysis, Graph Pad Prism software (version 5.0) was used to obtain standard curves and graphs, percentages of inhibition, averages and standard deviations.

\section{Results and Discussion}

\section{Results of the survey}

The survey allowed to exchange with 89 herbalists and traditional healers. These people consisted mainly of men, including 68 men. It was found that Acanthospermum hispidum is an herb that is widely used in traditional medicine in the Central West region against several diseases including mainly abdominal pain, eruptive fever, hepatobiliary disorders, microbial infections and other diseases.

Analysis of the table revealed that for the usual value (UV), the greatest value was recorded in the treatment of bacterial infections with calcination as a method of preparation (0.68). The decoction of Acanthospermum hispidum administered orally against abdominal pain presented the highest informant consensus factor (Table 1). As for the level of fidelity, a low value was observed at the level of the treatment of other diseases $(2.21 \%)$ whereas the strongest one was noted at the level of the treatment of the microbial diseases with Acanthospermum hispidum (Table 1).

\section{Results of pharmacological characterization}

\section{Image of the drug}

Photo (1a and b) shows the macroscopic appearance and the microscopic aspect of the plant drug. The appearance of the vegetable powder makes it possible to optimize the yield of the extractions.

\section{Histochemical characteristic}

The histochemistry of Acanthospermum hispidum is shown in Photo 2. The numbers 1 , $2,3,4,5,6$, of the photos respectively indicate the epidermis, the collenchyme, the medullary parenchyma, the sclerenchyma, the phloem, and the xylem of the stem of Acanthospermum hispidum.

The plant has a secondary tissue structure with a remarkable presence of hair on the aerial 
part. Flavonoids have been observed in the conductive vessels; tannins, they have been located in the epidermis and conducting vessels (photo 2). As for the alkaloids, they were found in trace at the level of the medullary parenchyma of the stem and the root (photo 2).

\section{Results of biological activities}

Inhibition of lipid peroxidation of rat tissue liposomes

The ethanolic extract of Acanthospermum hispidum gave a good ability to inhibit the peroxidation of the membrane lipids of the various organs compared with the aqueous extractwith $31.33 \pm 1.2 \mu \mathrm{g} / \mathrm{mL}$ as the inhibitory concentration of the peroxidation of $50 \%$ of rat liver lipids. The ascorbic acid used as the reference compound had a better activity compared to the extracts with respectively $5.5 \pm 1 \mu \mathrm{g} / \mathrm{mL}, 5.03 \pm 1.2 \mu \mathrm{g} / \mathrm{mL}$, $0.8 \pm 0.0 \mu \mathrm{g} / \mathrm{mL}$ and $10.5 \pm 0.9 \mu \mathrm{g} / \mathrm{mL}$, for inhibition of peroxidation of membrane lipids of the liver, lungs, kidneys, pancreas (Figure $1)$.

\section{Result of trapping hydrogen peroxide}

The ethanolic extract of Acanthospermum hispidum showed better ability to trap hydrogen peroxide compared to the aqueous extract.

Ancestral knowledge is an important basis in the search for solutions against the evils that undermine our societies. For years, African people have been resorting to herbalists and traditional healers when they have health problems (Makhanya 2012). These people, who are knowledgeable, tend to take care of medicinal plants. Acanthospermum hispidum is an herb widely used in the Central West region. Out of a total of 126 people surveyed (herbalists and traditional health practitioners),
89 recognized Acanthospermum hispidum for treatment. This high rate of use of Acanthospermum hispidum $(70.63 \%)$ could be justified by the large number of diseases that the plant treats, which in turn can be explained by the quality and diversity of the active molecules contained in this plant (Yuan et al., 2016).

Phenolic compounds such as tannins and flavonoids have been demonstrated in the tissues of Acanthospermum hispidum. Flavonoids have been found in the collenchyme of the stem and root. The presence of flavonoids in the tissues of this herb is in agreement with the work of Ouattara(Ouattara et al., 2011) which indicates that the aerial parts of Acanthospermum hispidum are rich in flavones. The presence of flavonoids in plant tissues is an indicator of the plant's defense mechanism against multiple aggressions (Ally et al., 2017). Phenolic compounds in general, and flavonoids in particular, are involved in plant defense mechanisms in the face of environmental threats such as temperature fluctuations, and UV radiation (Kulbat 2016). Flavonoids and terpenes are synthesized in plant tissues in response to infections (Guenne 2014). On the other hand, alkaloids and tannins, thanks to their toxic and astringent effect, defend the plant against insects and repel ruminants. The presence of these secondary metabolites such as flavonoids highlighted in histochemical sections may confirm the results of biological activities.

The antioxidant capacity of the ethanolic extract of the whole plant of Acanthospermum hispidum could highlight a capacity of this form of extract to act within the membrane lipid bilayer or on the lipophilic surfaces of lipoproteins and prevent the initiation of lipid peroxidation caused by biological radicals (Mothana et al., 2009b). 
Table.1 Results of the survey

\begin{tabular}{|c|c|c|c|c|}
\hline $\begin{array}{l}\text { Mode of } \\
\text { preparation }\end{array}$ & $\begin{array}{l}\text { Mode of } \\
\text { application }\end{array}$ & $\begin{array}{l}\text { Usual } \\
\text { value }\end{array}$ & $\begin{array}{l}\text { Factor } \\
\text { Consensus } \\
\text { Informant }\end{array}$ & $\begin{array}{l}\text { Loyalty Level } \\
(\%)\end{array}$ \\
\hline \multicolumn{5}{|c|}{$\begin{array}{l}\text { Treatment of hepatobiliary disorders (Mallmann } \text { et al., 2018), (Mothana et al., } \\
\text { 2009a) }\end{array}$} \\
\hline Decoction & Oral & 0.35 & 0.58 & \multirow[t]{2}{*}{20} \\
\hline Infusion & Oral & 0.25 & 0.42 & \\
\hline \multicolumn{5}{|c|}{$\begin{array}{l}\text { Treatment of abdominal pain (Lemonica and Alvarenga 1994), (Mihigo et al., } \\
\text { 2015), (Mallmann et al., 2018) }\end{array}$} \\
\hline Infusion & Oral & 0.21 & 0.25 & \multirow[t]{2}{*}{28,35} \\
\hline Decoction & Oral & 0.64 & 0.75 & \\
\hline \multicolumn{5}{|c|}{$\begin{array}{c}\text { Treatment of eruptive fever (Edewor and Olajire 2011), (Chinedu, Arome, and } \\
\text { Amed 2014; Herekrishna et al., 2010) }\end{array}$} \\
\hline Infusion & Oral & 0.25 & 0.26 & \multirow[t]{2}{*}{26,11} \\
\hline Decoction & Oral & 0.62 & 0.74 & \\
\hline \multicolumn{5}{|c|}{ Treatment of microbial infections (El-Ghani 2016), (Onguéné et al., 2014) } \\
\hline Calcination & $\begin{array}{l}\text { Application on } \\
\text { the skin }\end{array}$ & 0.68 & 0.67 & \multirow[t]{3}{*}{33.34} \\
\hline Infusion & Oral & 0.15 & 0.15 & \\
\hline Decoction & Oral & 0.19 & 0.18 & \\
\hline \multicolumn{5}{|c|}{ Treatment of other diseases (El-Ghani 2016), } \\
\hline $\begin{array}{l}\text { Infusion, } \\
\text { Decoction, } \\
\text { Inhalation and } \\
\text { Calcination }\end{array}$ & $\begin{array}{l}\text { Oral, bath, } \\
\text { application to } \\
\text { the skin, } \\
\text { inhalation }\end{array}$ & 0.09 & 0.05 & 2.21 \\
\hline
\end{tabular}

Fig.1 Central West Region, Sannguié Province (survey area) https://fr.wikipedia.org/wiki/Centre-Ouest_(Burkina_Faso)\#/media/Fichier:Burkina_Faso__Centre-Ouest.svg(accessed August 03, 2019)

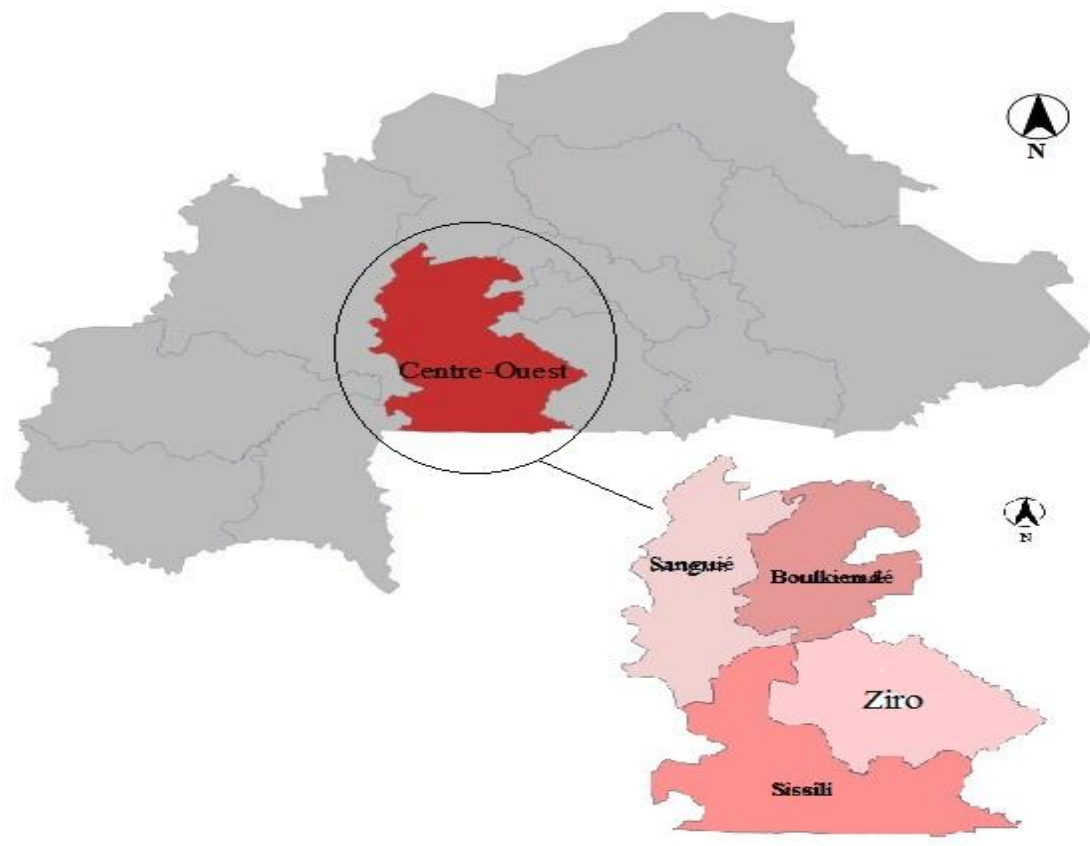


Fig.2 Inhibition of lipid peroxidation of liposomes from rat tissues

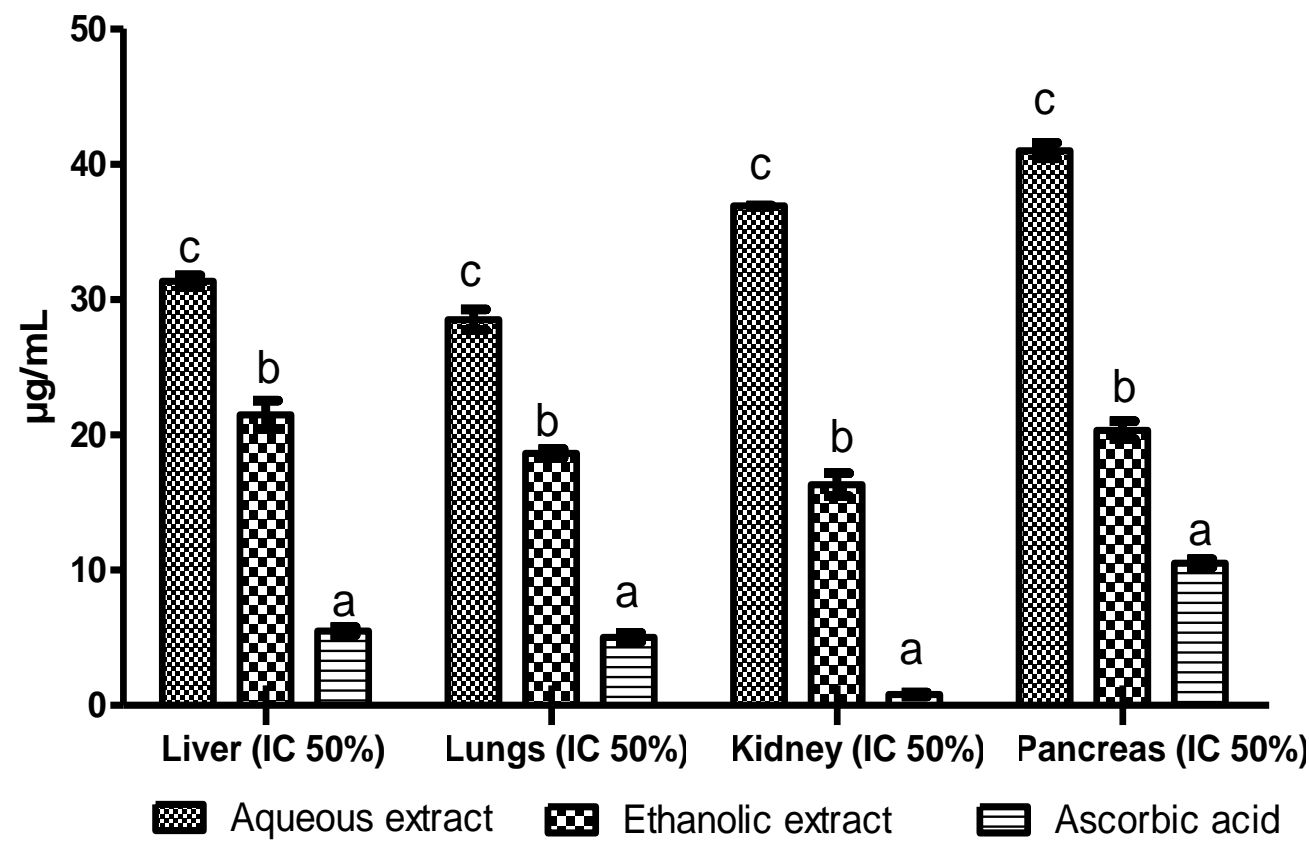

A significant difference is considered for $\mathrm{p}=0.05$

Fig.3 Result of trapping hydrogen peroxide

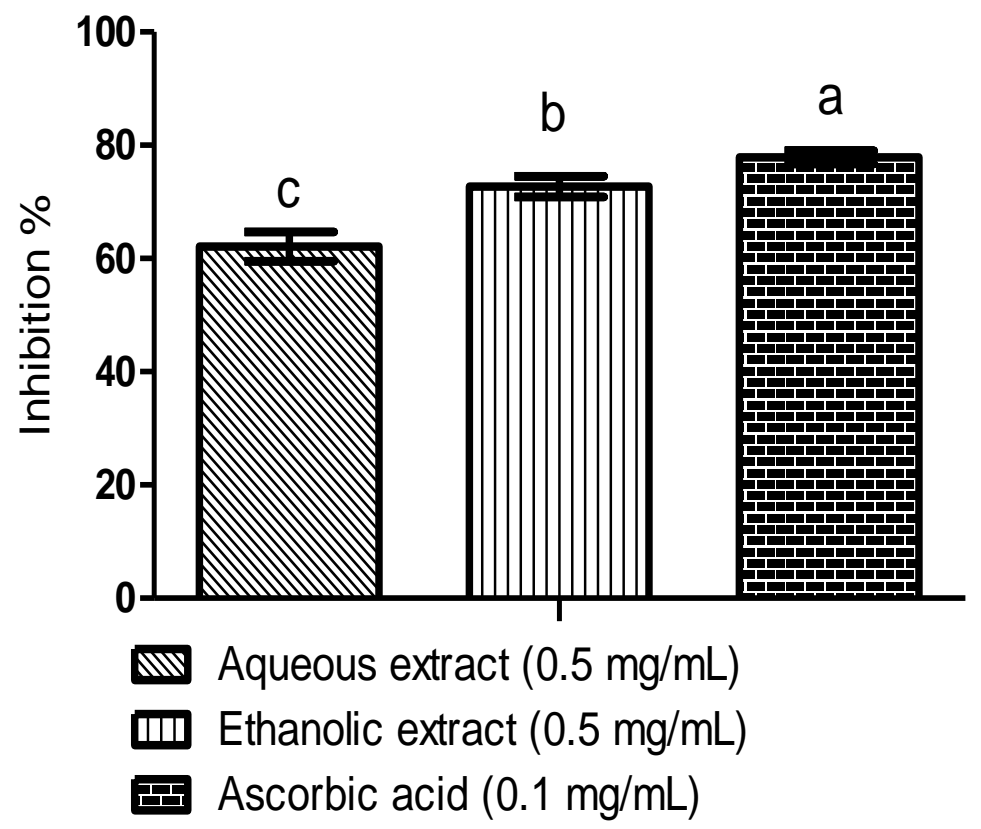

A significant difference is considered for $\mathrm{p}=0.05$ 
Photo.1 Macroscopic (a) and microscopic (b) aspects of the plant drug
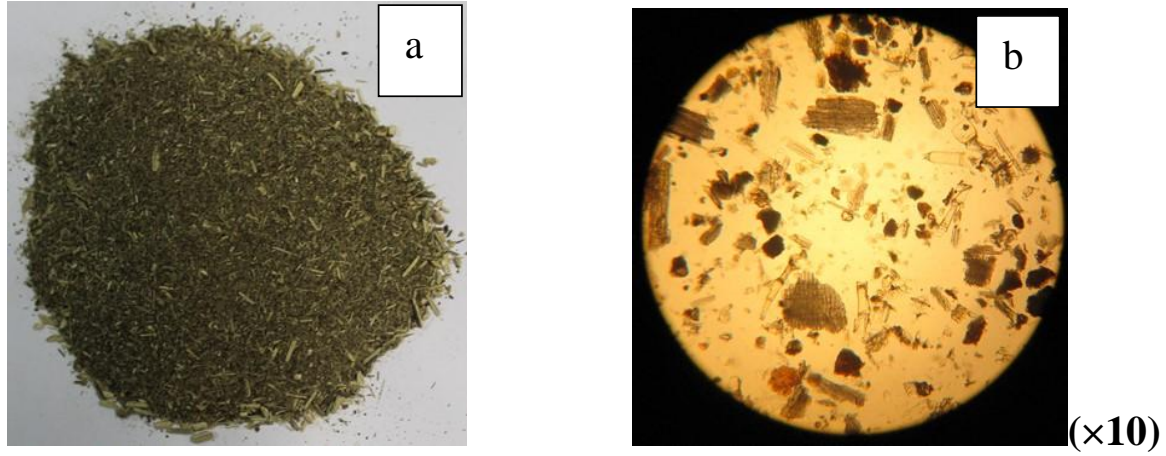

Photo.2 Histochemical sections of Acanthospermum hispidum DC

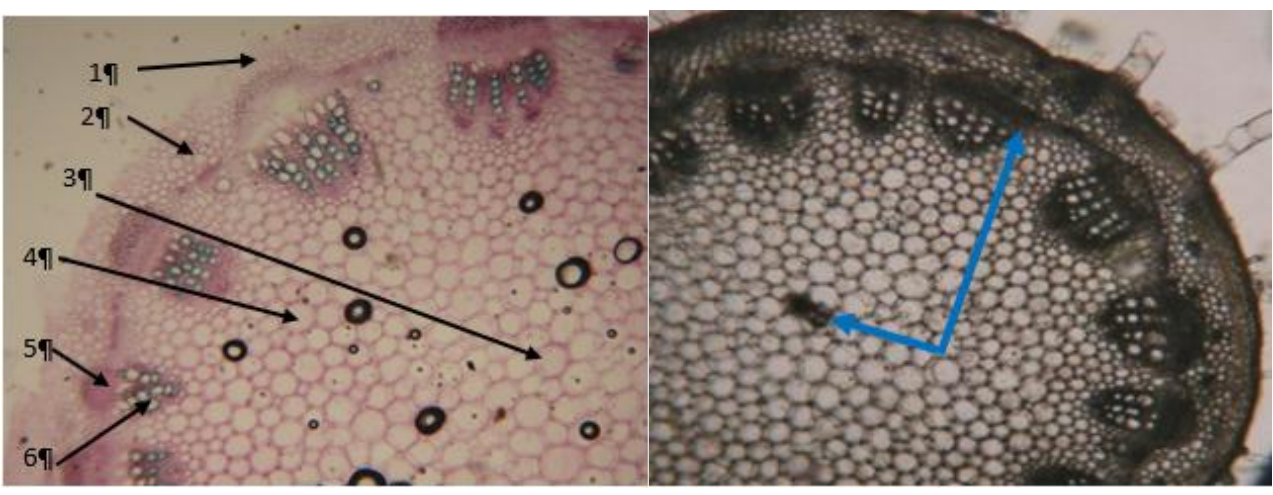

Tissue structure (Stem)

Alkaloid Test (Stem)
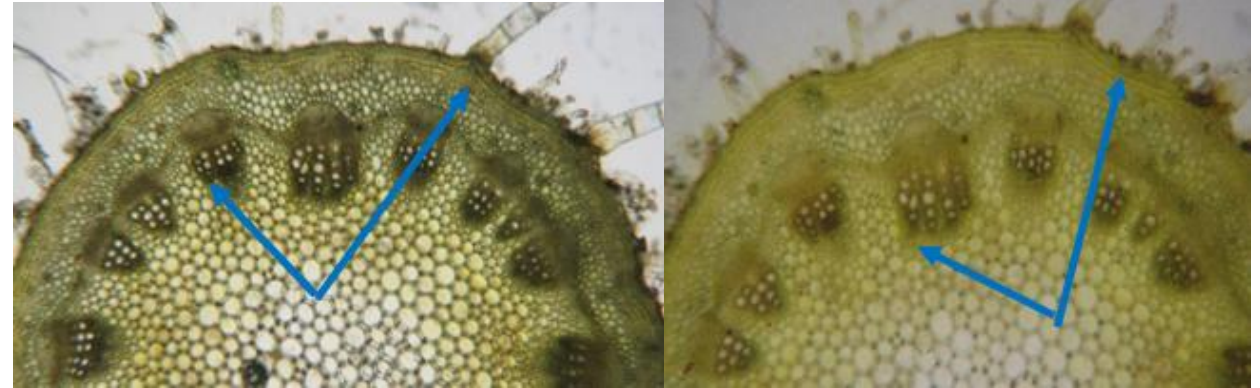

Tannin and Polyphenol Test (Stem)

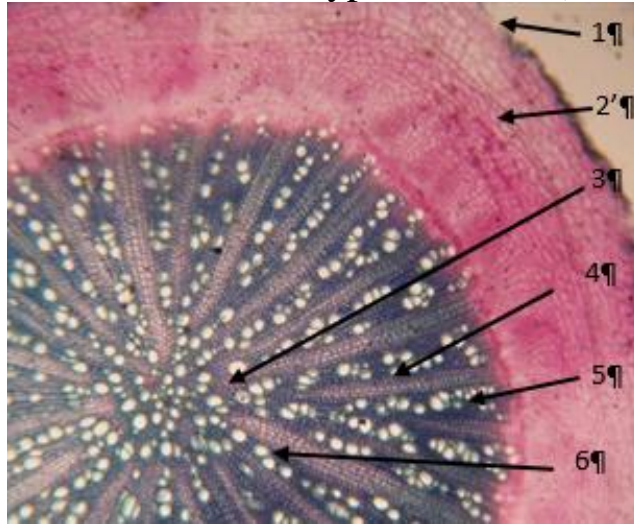

Tissue Structure (Root)
Flavonoid Test (Stem)

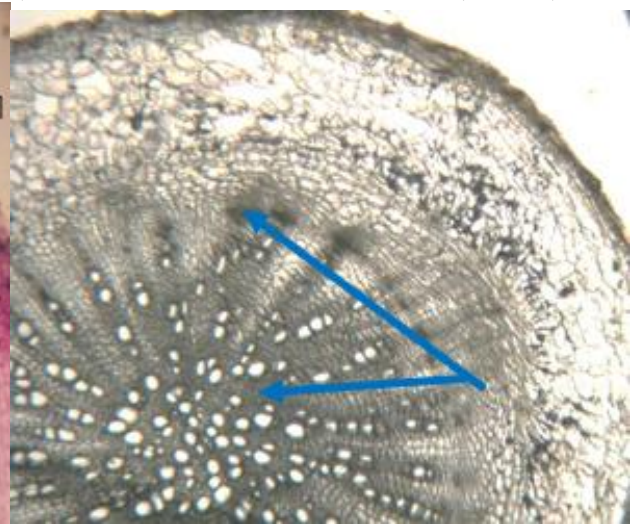

Alkaloid Test (Root) 


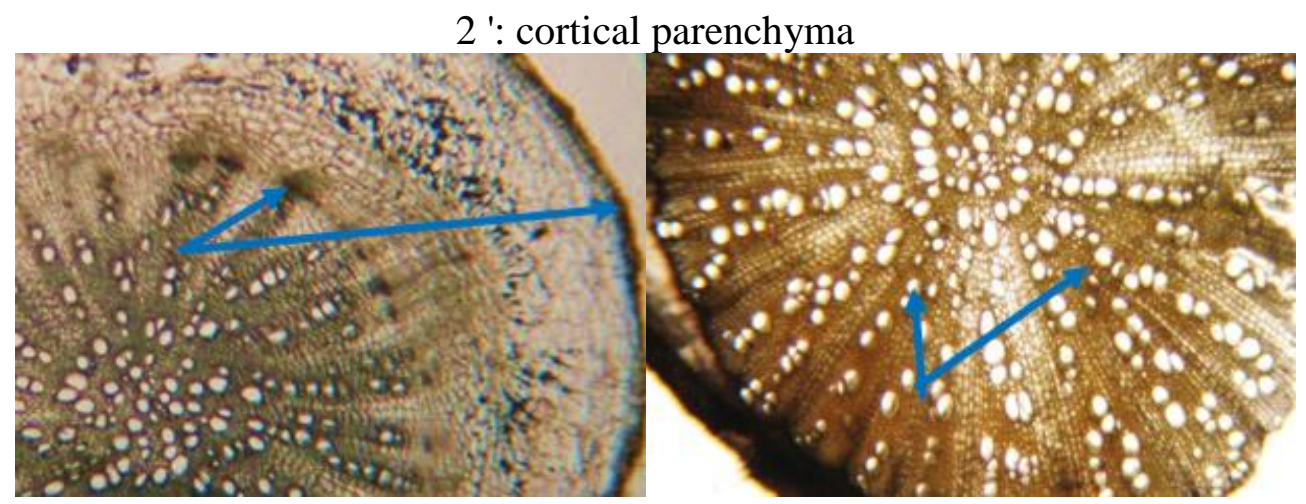

Tannin and polyphenol test (Racine) Flavonoid test (Racine)

The ethanolic extract also trapped in this study the hydrophilic radicals (hydroxyl radical), explaining at the same time that this extract would trap the primary radicals present in the aqueous phase (cytosol), or in the polar sites of membrane phospholipids (Fardet 2017). All these arguments would argue in favor of this strong use of this herb in traditional medicine against various.

In conclusion, the macroscopic and microscopic aspects of the vegetable powder have made it possible to obtain satisfactory extraction yields. Phytochemical screening confirmed the tissue structure and localization of secondary metabolites in the tissues of Acanthospermum hispidum. Extracts of Acanthospermum hispidum play a chemoprotective role against oxidative stress. By their reducing power against the reactive species, the extracts have an antioxidant activity. The alkaloids detected in plant tissues in addition to phenolic compounds highlight the richness of natural substances of Acanthospermum hispidum. Each group of compounds highlighted is a therapeutic potential. This probably justifies the use of this plant in traditional medicine against diseases.

\section{Acknowledgements}

The pharmacognosic characterization was carried out at the Laboratory of Biochemistry and Applied Chemistry (LABIOCA) of the University of Ouaga I Pr Joseph KI-ZERBO. We thank all traditional healers and herbalists in the Central West Region (Burkina Faso) for their frank collaboration.

\section{References}

Ally, Adrian et al., (2017). "Comprehensive and Integrative Genomic Characterization of Hepatocellular Carcinoma." Cell 169(7): 13271341.e23.

Canales, M et al., (2005). "Informant Consensus Factor and Antibacterial Activity of the Medicinal Plants Used by the People of San Rafael Coxcatlan, Puebla, Mexico." Mexico, Journal of Ethnopharmacolog 97: 429-39.

Cheikhyoussef, Ahmad, Martin Shapi, Kenneth Matengu, and Hina $\mathrm{Mu}$ Ashekele. (2011). "Ethnobotanical Study of Indigenous Knowledge on Medicinal Plant Use by Traditional Healers in Oshikoto Region, Namibia." JOURNAL OF ETHNOBIOLOGY AND ETHNOMEDICINE 7(10): 1-11.

Chinedu, Enegide, David Arome, and Solomon F. Amed. (2014). "African Herbal Plants Used as Anti-Malaria Agents-A Review." Pharmacy infopedia 2(3): 1-150.

Cronquist, A. (1981). New York: Columbia University Press An Integral System of 
Classifi Cation of Fl Owering Plants.

Edewor, Theresa I., and Abass A. Olajire. (2011). "Two Flavones from Acanthospermum Hispidum DC and Their Antibacterial Activity Theresa." International Journal of Organic Chemistry 01(03): 132-41. http://www.scirp.org/journal/doi.aspx? DOI=10.4236/ijoc.2011.13020.

El-Ghani, Monier M Abd. (2016). "Traditional Medicinal Plants of Nigeria: An Overview." Agric. Biol. J. N. Am. 7(5): 220-47.

Fardet, Anthony. (2017). "Le Pouvoir Antioxydant Des Produits Laitiers Une Propriété Méconnue de Leur Potentiel Protecteur." Choledoc 155(3): 1-4. https://www.cerin.org/wpcontent/uploads/woocommerce_uploads /2017/02/155-pouvoir-antioxydantproduits-laitiers.pdf.(French)

Gomathi, V., B. Jaykar, and P. Palanisamy. (2013). "Preliminary Phytochemical and In-Vitro Antioxidant Activity of the Whole Plant of Acanthospermum Hispidum Dc." International Journal of Medicine and Pharmacy 1(1): 22-32.

Goodridge, D. (2007)."Journal of Psychiatric and Mental Health Nursing Review of Complementary and Alternative Medicine for Older Adults: A Guide to Holistic Approaches to Healthy Aging". http://ovidsp.ovid.com/ovidweb.cgi?T= $\mathrm{JS} \& \mathrm{PAGE}=$ reference $\& \mathrm{D}=\mathrm{psyc} 5 \& \mathrm{NEW}$ $\mathrm{S}=\mathrm{N} \& A N=2007-01011-018$.

Guenne, Samson. (2014). Université de Ouagadougou "Potentiels Hépatoprotecteurs de Trois (03) Asteraceae Utilisées En Médecine Traditionnelle Du Burkina Faso: Chrysanthellum Americanum (L.) Vatke, Eclipta Alba (L.) Hassk. et Vernonia Colorata (Willd.) Drake." Université de Ouagadougou.(French)

Herekrishna, R. et al., (2010). "Preliminary Phytochemical Investigation and
Anthelmintic Activity of Acanthospermum Hispidum DC." Journal of Pharmaceutical Science and Technology 2(5): 217-21.

Kulbat, Kamila. (2016). "The Role of Phenolic Compounds in Plant Resistance." Biotechnology and Food Sciences 80(2): 97-108.

Lemonica, I. P., and C. M.D. Alvarenga. (1994). "Abortive and Teratogenic Effect of Acanthospermum Hispidum DC. and Cajanus Cajan (L.) Millps. in Pregnant Rats." Journal of Ethnopharmacology 43(1): 39-44.

Makhanya, S.M. (2012). "The Traditional Healers' and Car e Givers' Views on the Role of Traditional Zulu Medicine on Psychosis." University of Zululand.

Mallmann, R et al., (2018). "Effectiveness of Aqueous and Hydroalcoholic Extracts of Acanthospermum Australe ( Loefl.) Kuntze against Diarrhea-Inducing Bacteria." Braz. J. Biol.: 1-6.

Mihigo, Shetonde O., Luvenga Ndombele, Ishmael B. Masesane, and K. Sichilongo. (2015). "International Journal of Chemistry and Aquatic Sciences." International Journal of Chemistry and Aquatic Sciences 1(1): 55-64.

Ministère, de, l'économie, et, des, finances, Burkina. (2011). La Région Du CentreOuest.(French)

Ministère, l'agriculture, et, de, L' Hydraulique, Burkina Faso. (2010). Enquête Nationale Sur l'accès Des Ménages Aux Ouvrages d'assainissement Familial 2010.(French)

Mothana, Ramzi A., Ulrike Lindequist, Renate Gruenert, and Patrick J. Bednarski. (2009a). "Studies of the in Vitro Anticancer, Antimicrobial and Antioxidant Potentials of Selected Yemeni Medicinal Plants from the Island Soqotra." BMC Complementary 
and Alternative Medicine 9: 1-11.

Mothana RA, Lindequist U, Gruenert R. et al., (2009b). "Studies of the in Vitro Anticancer, Antimicrobial and Antioxidant Potentials of Selected Yemeni Medicinal Plants from the Island Soqotra." BMC Complementary and Alternative Medicine 9(April).

Nacoulma, Odile G. (1996). "Plantes Médicinales et Pratiques Médicinales Traditionnelles Au BURKINA." Université de Ouagadougou.(French)

Ogbunugafor, Henrietta et al., (2012). "In Vitro and In Vivo Evaluation of Antioxidant Properties of Moringa Oleifera Ethanolic Leaves Extract and Effect on Serum Lipid Indices in Rat." Macedonian Journal of Medical Sciences 5(4): 397-403.

Onguéné, Pascal Amoa et al., (2014). “The Potential of Anti-Malarial Compounds Derived from African Medicinal Plants, Part III: An in Silico Evaluation of Drug Metabolism and Pharmacokinetics Profiling." Organic and Medicinal Chemistry Letters 4(1): 6. http://www.orgmedchemlett.com/conten $\mathrm{t} / 4 / 1 / 6$.

Ouattara, M. B. et al., (2011). "Antibacterial Potential and Antioxidant Activity of Polyphenols of Sesbania Pachycarpa Antibacterial Potential and Antioxidant
Activity of Polyphenols of Sesbania." African Journal of Scientific Research 5, No. 1: 17.

Sarr, Oumar, Amy Bakhoum, Sékouna Diatta, and Léonard E Akpo. (2013). "L ' Arbre En Milieu Soudano-Sahélien Dans Le Bassin Arachidier ( CentreSénégal )." Journal of Applied Biosciences 61(ISSN 1997-590): 451529.(French)

Su, A Xiao-Yu et al., (2009). "In Vitro and in Vivo Antioxidant Activity of Pinus Koraiensis Seed Extract1.Pdf." Food Chemistry: 681-686.

Verdi, L.G., I.M.C. Brighenete, and M.G. Pizzolatti. (2005). "Gênero Baccharis (Asteraceae): Aspectos Químicos, Econômicos e Biológicos." Quim Nova 28: 85-94.

Yelemou, B., B. A. Bationo, G. Yameogo, and J Millogo-Rasolodimby. (2007). "Gestion Traditionnelle et Usages de Piliostigma Reticulatum Sur Le Plateau Central Du Burkina Faso TRADITIONAL USE AND." Bois et forêts des tropiques 291(1): 5566.(French)

Yuan, Haidan, Qianqian $\mathrm{Ma}, \mathrm{Li} \mathrm{Ye}$, and Guangchun Piao. (2016). "The Traditional Medicine and Modern Medicine from Natural Products." Molecules 21(559): 18.

\section{How to cite this article:}

Jotham Yhi-pênê N'do, Adama Hilou, Dramane Pare, Samson Guenne and André Tibiri. 2019. Ethnobotany and Pharmacognosic Characterization of Acanthospermum hispidum (Asteraceae), A Medicinal Plant widely used in Traditional Medicine in the Central West Region (Burkina Faso). Int.J.Curr.Microbiol.App.Sci. 8(09): 97-108. doi: https://doi.org/10.20546/ijcmas.2019.809.014 